\title{
A Qualitative Study on the Perception of Fatherhood
}

\author{
Tanju Gurkan, PhD \\ Ankara University, Retired faculty member, Turkey \\ Azize Ummanel, EdD \\ European University of Lefke, North Cyprus \\ Nihan Koran, $P h D$ \\ Eastern Mediterranean University, North Cyprus
}

Doi:10.19044/ejes.v8no2a42

URL:http://dx.doi.org/10.19044/ejes.v8no2a42

Submitted: 25 March 2021

Accepted: 31 May 2021

Published: 30 June 2021
Copyright 2021 Author(s)

Under Creative Commons BY-NC-ND

4.0 OPEN ACCESS

\begin{abstract}
:
The changing structure of the society and the increase in the number of working women has been influential on the relationship between the child and the parent. Today, the woman, who is responsible for the nutrition and care of the child according to the traditional point of view, can perform these duties not on her own but with her husband and the basic needs of the child can be provided by the parents together. Therefore, the role of fatherhood has changed and fathers have become more involved in meeting the basic needs of the child. This study aims to explore how men perceive fatherhood and how mothers perceive their husband's fatherhood. 15 fathers and 15 mothers were included in the study. Mothers and fathers were interviewed to collect the data and the data were examined under the main categories of "Fatherhood self-assessment" and "Fatherhood role perception." The results provide insight into how fathers parenting children between the ages of 3 and 6, how they perceive their fatherhood and how mothers perceive their husband's fatherhood. Furthermore, results were obtained about how parents define fatherhood and which roles they associate fatherhood with. In conclusion it was found that fathers have a traditional perception on fatherhood, and the results were discussed in this context. As it is one of the first studies on fatherhood conducted in the TRNC, this study has importance and similar studies are suggested to carried out.
\end{abstract}

Key Words: Fatherhood, fatherhood role perception, TRNC.

\section{Introduction}

Starting from a young age, we demonstrate roles in our games that we may encounter in the later years of our lives; however, this time, we experience them as a fact of life, not as a game. One of these roles is undoubtedly parenting. While several studies related to motherhood and fatherhood prevail in the literature, studies related to fatherhood, in particular, have increased only in recent years.

Fatherhood, just like motherhood, emerges as an element of the social structure created under the institution of marriage; this structure is greatly influenced by the traditional way of life, thus forming different roles. From the traditional viewpoints of the Western and Eastern societies, a father works outside of the house and carries the responsibility of economically supporting the 
family and a mother takes care of the house and children (Atmaca Kocak, 2004; McKeown, 2001; Pontes, Osorio \& Alexandrino, 2009). Parenting is not biological; it comprises various roles wherein a man who fathers a child can be called "a father," even if he does not share a biological connection with the child (Richardson, 1995).

Within the family dynamics, mothers and fathers are responsible for the nutrition, protection, and the physical and emotional needs of a child; they play an active role in developing a child's personality and transferring social values to the child (Gungorduz, 2010). This unwritten agreement for the division of work among family members is influenced by cultural values; however, it can alter in accordance with economic ties (Coltrane, 1995; Dick, 2001). Further, a rise in the paternal involvement in childcare and a change in the traditional roles have been observed, as women are actively participating in maintaining a work-life balance (Bayer, 2020; Gursimsek, Kefi \& Girgin, 2007; Raven \& Sevim, 2004; Stubley, Rojas \& McCroy, 2015). While the roles of a father who inculcates discipline, plans the future, interacts with the world outside of the family (Respect, 2008, p. 131) are changing, many fathers have begun experiencing the stress of managing economic support and facilitating paternal involvement (McKeown, 2001). Moreover, with the child's responsibilities being attributed to the mother and men leaving the traditional status of fatherhood wherein their roles are limited, a father's dilemma associated with the loss of masculinity is an evident phenomenon (Beyazit \& Famagden, 2015).

Undoubtedly, changes in men's paternal roles in today's family life entail a closer fatherchild relationship. However, fathers worldwide spend much less time on childcare than mothers (Engle, 1997). Thus, investigating the ways in which men perceive fatherhood is vital. According to the traditional understanding, men perceive fatherhood as being the breadwinner of the house, the head of the family, a link between the family and the world outside, playing with the child, being responsible for the education and discipline of the child, and being a parent who protects their child (Summers et al., 1999). While fathers in Japan associate fatherhood with the concepts of discipline and authority (Kutz, 1994), fathers in Zimbabwe cannot hide their astonishment as they are informed about the importance of playing with the child from an early age (Engle, 1997). Although American fathers do not give their children more time for activities such as reading books, storytelling, and singing, they demonstrate behaviors such as changing diapers, preparing food, and feeding their children (Bronte-Tinkew, Carrano \& Guzman, 2006). In Turkey, the perception of fatherhood is shaped around aspects such as ensuring the livelihood of the household, undertaking new responsibilities, and being in an authoritative position and providing protection. Among these points, the most crucial one is to ensure the livelihood of the household. While this aspect is becoming more prominent, new responsibilities such as caring for, showing love to, supporting, and being friends with the children are not very robust (Tol \& Taskan, 2018). Studies conducted in Turkey indicate that the perception about fatherhood varies according to the father's age, level of education, and the age at which they first became a father, i.e. (Aksoy \& Tatl1, 2019; Guzel \& Tufekci, 2021; Telli \& Özkan, 2016), as the age and experience of being a father increase, one's perceptions about fatherhood shifts from the traditional structure, and with an increase in the educational level, fathers become more sensitive to their child's needs and participate more in advancing child care (Gultekin Akduman \& Turkoglu, 2013). In addition, researchers hold similar viewpoints regarding fathers with increased educational levels taking more responsibility as parents, as they become more democratic, have more flexible gender roles, and consider themselves more adequate in rendering child development (Coltrane, 1995; Model, 1981; Russell, 1982). 
As the perception of fatherhood changes, paternal roles also change. Although variables such as education, income level (Bronte-Tinkew, Carrano \& Guzman, 2006), age, experience (Gultekin Akduman \& Turkoglu, 2013), and participation in infant care courses (Lewis \& Warren, 2001, as cited in McKeown, 2001, p. 6) affect the perception of fatherhood, the notion of a mother also influences this aspect (Parquet, 2002; Parquet, 2004; Rohner \& Veneziano, 2001). Fathers' primary source of learning about childcare is their spouses (Scarzello, Arace \& Prino, 2016). However, if a father's weekly working time is less than that of the mother, fathers can be more involved in childcare (NICHD Early Childcare Research Network, 2000). Although fathers perceive themselves as a breadwinner and the mother as a person who is responsible for rendering physical care to children (Evans, 1997; Advice, 1998), the participation levels of the middle and upper class fathers in child care increases when the mother begins to work outside of the house (Yilmazcetin, 2003).

Although fathers have concerns about their masculinity, they spend more time with their families and participate more in childcare than in the previous century (Mercan \& Sahin, 2017). This aspect gives fatherhood a more contemporary status and makes fathers happier, more expressive, emotional, and companionable individuals (Cullen \& Grossman, 2007). Colombian fathers state that instead of being the family's breadwinner and an authoritative figure, they want to be more involved with the family and in the lives of their children; they want to show more love and devotion (Carrillo et al., 2016). In Finland, especially in the past 30 years, paternal involvement has increased. With the shift in the cultural expectation of fathers and the perception of men as parents, they have begun to be more caring toward their children. A study stated that Finnish fathers believe that participating in childcare in the early years is an indicator of responsible fatherhood; Finnish fathers have shifted from being the breadwinner to being the ones who share parenting roles and show more emotional support (Eerola, 2015). American fathers (Bronte-Tinkew, Carrano \& Guzman, 2006) who already collaborated on matters regarding caretaking, such as changing diapers, food preparation, and feeding, also became more involved in their children's health problems in recent years (US Census Bureau, 2013; Yogman et al., 2016). Qatari men emphasize that fathers have a significant role in child development, but they regard themselves as non-egalitarian parents. While young fathers, in particular, noted that showing love to the child is an important paternal role, others argued that the matter of childcare should be handled equally. These fathers categorized errands such as playing games with the child, answering the child's questions, feeding, and dressing them up among the least important ones. This factor suggests that Qatari fathers are changing their mindsets but have not yet overcome the traditional viewpoint (Shafaie et al., 2014). In Turkey, the main determinant of paternal roles is the mother's working status; if the mother does not work, then the father displays a traditional attitude toward childcare and education, and if the mother works, the spouse shares such responsibilities (Tutkun \& Tezel Sahin, 2016). According to Tol and Taskan (2018), fathers in Turkey are participating more in household chores, childcare, and their upbringing than in the past. Hence, the gap in father-child relationship is decreasing, girls are being valued, and behaviors such as caring and listening are becoming widespread.

Previous studies show striking results on the perception of fatherhood and the changes in paternal roles. A study revealed that some fathers want to be more involved in the care and upbringing of their children, while several fathers want to have closer emotional relationships with their children (Dick, 2011). Another similar study highlighted that fathers are aware that they have a significant place in their children's life and want to play an active role in it (Garfield \& Chung, 2006). 
This study learns about the perceptions of fatherhood of married couples living in Northern Cyprus; therefore, how men perceive fatherhood and how mothers perceive their husband's fatherhood are the topics of research. This study was inspired by the research conducted on fatherhood, as a phenomenon, in Turkey with the support of Mother Child Education Foundation (ACEV). Tol and Taskan (2018) categorized fatherhood as traditional, new traditional, diligent, keen, and exceptional fatherhood. Traditional fathers represent fathers that refuse to change, are authoritarian in nature, and who establish distant relationships with their children; characteristics such as being the rock of the family, the oak tree, the pillar of the house, the head of the family, strong, self-sacrificing, heroic, and protective are attributed to them. New traditional fathers refer to fathers who, while adopting the values of traditional fatherhood, have managed to overcome distance, particularly in the relationship with their daughters. Diligent fathers act contrarily to traditional gender roles as a responsibility. Keen fathers continue to hold the traditional perception of fatherhood but exhibit diligent paternal behaviors with their own decisions and opinions; such fathers undergo transformation with respect to father involvement. Finally, exceptional fathers are egalitarian in nature and have eliminated distances in the relationship with their children. According to Tol and Taskan (2018), more than a third of fathers in Turkey demonstrate traditional fatherhood characteristics. Traditional fathers are followed by new traditional fathers and keen or diligent fathers. Coming across exceptional fathers is hardly possible.

While no studies about fatherhood are found in Northern Cyprus, the legal description handles fatherhood biologically; fatherhood is confined on the basis of gender, not the roles. Therefore, the social perspective is also considered to be traditional. On the contrary, although the Turkish Cypriots have similar Turkish cultural and social traits, they have different family dynamics, i.e., egalitarian Turkish families based on equal control due to modern education and culture are found in Northern Cyprus (Alicik, 1997); both contemporary and traditional features are protected within the family structure in Turkey (Bayer, 2013; Ekici, 2014; Ulus, 2015). Therefore, the fatherhood phenomenon of Turkish Cypriots was worthy to be examined under a separate study.

\section{Method}

This section contains information about the research design, study group, data collection tool, data collection process, and data analysis.

\section{Research Design}

This study is a qualitative study structured according to the phenomenological pattern. Studies conducted with phenomenological pattern determine the participants' experiences and interpretations related to a given phenomenon. The important aspect of such studies is to reveal the viewpoints and perspectives people involved in the study on a given phenomenon. Phenomenological studies often use the interview method to obtain in-depth information from participants. In phenomenological studies, the researcher makes interpretations regarding the participants' experiences and elucidates the phenomenon (Creswell, 2013; Neuman, 2008).

\section{Study Group}

The study group was determined through convenience and purposive sampling; in all, there were 30 participants, including 15 fathers and 15 mothers. All participants were born in Cyprus and have children between the ages of 3 and 6 . The average age of the fathers and mothers participating in the study was 39 and 36 years, respectively. Further, nine families had one child, 
and six families had two children; these participants did not have more than two children; among the participating fathers, two completed middle school, three completed high school, four graduated from university, two possessed master's degrees, and four were doctoral graduates, and among the participating mothers, one completed primary school, one completed high school, six graduated from university, one possessed a master's degree, and six were doctoral graduates (see Table1). Further, the researchers informed the participants about the research and obtained their verbal consent.

Table 1. Demographic characteristics of the participants

\begin{tabular}{|c|c|c|c|}
\hline & Gender & Average Age & Educational Status \\
\hline \multirow[t]{6}{*}{ Women } & 15 & 36 & Primary School = 1 \\
\hline & & & Middle School = 0 \\
\hline & & & High School = 1 \\
\hline & & & University $=6$ \\
\hline & & & Master's = 1 \\
\hline & & & Doctorate $=6$ \\
\hline \multirow[t]{6}{*}{ Men } & 15 & 39 & Primary School $=0$ \\
\hline & & & Middle School = 2 \\
\hline & & & High School = 3 \\
\hline & & & University $=4$ \\
\hline & & & Master's $=2$ \\
\hline & & & Doctorate $=4$ \\
\hline Total & 30 & 37.5 & 30 \\
\hline
\end{tabular}

\section{Data Collection}

The study employed the interview method from the qualitative data collection methods as a data collection tool. Semi-structured questions were determined by the researchers for the interviews; these questions were sent to three experts, whose research area is qualitative studies and social sciences, and were rearranged following their recommendations. In addition to demographic information, the participants were asked five questions. A modified version of the questionnaire that was formulated for the fathers was also administered to the mothers. For example, questions such as "How do you spend time with your child?" and "Which one of your mentions do you do the most?" that were directed to the fathers were rephrased and directed to the mothers in the following manner: "How does your partner spend time with your child?" and "Which one of your mentions does your husband do the most?" This study conducted face-toface or telephone interviews based on the participants' preferences. The interviews were scheduled in accordance with the participants availability and lasted for an average of 22 min. The interviews were recorded with the permission of the participants and the voice records of interviews were transformed in to written format.

\section{Data Analysis}

The collected data were analyzed through the content analysis method and examined under categories created through themes. In the content analysis method, the obtained data were first encoded and then divided into themes. While encoding, data containing the same themes were grouped and defined. Thus, the information obtained from the data was more meaningful (Yıldırım \& Şimşek, 2016). In the first stage of data analysis, interview records were examined, codes and categories were defined. The data obtained from interviews were examined under the categories 
of "fatherhood self-assessment" and "perception of fatherhood". After the codes and categories were defined, the interview records were examined again and the data were analyzed according to the codes extracted from the data. Thus, a systematic structure has been created in which the data can be arranged in a systematic way (Maxwell, 2008; Merriam \& Greiner, 2019). In all, two researchers performed the analysis of the data, and Miles and Huberman's (1994) reliability formula was applied during the analysis process. The formula result was $52 /(52+5) \times 100=$ $91.2 \%$. As the result was more than $70 \%$, it indicated that the study is reliable (Miles \& Huberman, 1994). The data obtained from interviews were examined under "fatherhood selfassessment" and "perception of fatherhood" categories.

\section{Findings}

This study reviewed the data obtained from the participants under two main categories, namely, "fatherhood self-assessment" and "perception of fatherhood."

\section{Fatherhood Self-assessment}

Under this category, topics such as the definition of fatherhood according to the fathers, the type of father they are in their opinion, the type of father their husbands are according to the opinions of the mothers, how they spend time with their children as per their opinion, and how fathers spend time with their children according to the opinions of the mothers were analyzed.

T able 2. Definition of fatherhood according to the participating fathers

\begin{tabular}{ll} 
& $f$ \\
\hline Happiness & 9 \\
\hline Responsibility & 7 \\
\hline Life source & 4 \\
\hline Total & 20 \\
\hline
\end{tabular}

On analyzing the responses of the participating fathers, the study revealed that nine fathers described fatherhood as happiness, eight fathers as responsibility, and four fathers as life source (see Table2). Fathers who described fatherhood as happiness quoted the following statements: "He/she (the child) is a source of happiness, I couldn't understand (life) before him/her, I can't imagine a life without him/her." (F11) and "Having children means happiness. One feels very happy." (F12). Fathers who defined fatherhood as responsibility quoted the following statements: "Being a father means responsibility, first of all. There are responsibilities related to school and health. I have responsibilities such as the child seeing me before he/she goes to sleep." (F8) and "(Fatherhood) refers to responsibility like the responsibility of finance and health. It is important to financially meet all the needs." (F14). Fathers who defined fatherhood as a life source quoted the following statements: "The beginning of my life, my life source." (F6) and "He/she is like life. My life starts with him/her. I don't know how it would go on without him/her.” (F7).

Table 3. Type of father they are according to the participating fathers' viewpoints

\begin{tabular}{ll} 
& $F$ \\
\hline Self-sacrificing & 6 \\
\hline Plays games & 5 \\
\hline Spends quality time & 3 \\
\hline Affectionate & 2 \\
\hline Total & 15 \\
\hline
\end{tabular}


When the responses given by the 15 fathers were analyzed, six fathers defined themselves as self-sacrificing, five fathers as the type who play games with their children, three fathers as the type who spend quality time with their children, and two as the affectionate type (see Table3). Fathers who described themselves as self-sacrificing quoted the following: "Selfsacrificing. Every step I take, I think of my family, I think of my children's future." (F4) and "I'll do my best for them. I think of them more than I think about myself. I spare no sacrifices." (F14). The statements of those who defined themselves as fathers who play games with their children include the following: "I usually play with him/her when I spend time with him/her. I'm his/her playmate." (F13) and "We play as many games as we can. We're like kids." (F2). Statements of those who defined themselves as fathers who spend quality time with their children are "We do experiments and build trains to spend quality time together. Although, I spend little time with him/her, I try to offer him/her some valuable things during this time. Not only games, but I also share some vital information with him/her; for example, how trains work." (F13) and "I try to spend quality time; like instead of buying toys, we make them. I'll try to use our dexterity. Quality time is important." (F5). Further, fathers who described themselves as affectionate stated, "I am a father who gives happiness and loves their children. It is very important for me that they know and feel this love." (F7) and "I am a person who gives love. (My) Children should know and understand that I love them just like their mother does." (F15).

$\mathrm{T}$ able 4. Type of father their husbands are according the viewpoints of the participating mothers

\begin{tabular}{ll} 
& $f$ \\
\hline Involved & 4 \\
\hline Plays games & 4 \\
\hline Responsible & 4 \\
\hline Angry & 3 \\
\hline Total & 15 \\
\hline
\end{tabular}

When the responses given by the 15 participating mothers were analyzed, four mothers stated that their husbands were involved fathers, four described their husbands as the type of fathers that play games, four said that their husbands were responsible fathers, and three claimed that their husbands were angry fathers (see Table4). The statements of mothers who identified their spouses as an involved father included "He takes care of the children's every need. He knows what they like and their rhythm. If you ask me if I prefer a babysitter or their dad, I'll say dad because he is very involved." (M3) and "He is very involved in the house and with children. He pays attention to their activities. He runs errands. He deals with their lessons. Sometimes, he works a lot, but he makes sure that he is involved." (M15). The mothers who defined their husbands as fathers that play games stated, "He is a playmate even more than me. He loves this role and enjoys playing games." (M1) and "He actually has many traits, but he plays games the most, so he is the playmate." (M7). The following are the statements of mothers who described their spouses as responsible fathers: "He knows his responsibilities. He does not neglect his son and does not avoid responsibility" (M2) and "He got better with time. When our child was a baby, he would avoid taking responsibility, and as the child grew, he started taking more responsibility like taking them to school, activities, and shopping." (M13). Some expressions of mothers who identified their spouses as angry fathers included "He is angry. He's gets frustrated because he's impatient. He gets angry at children" (M7) and "He gets angry very quickly, and when he gets angry, he leaves everything. Actually, the kids do not do anything serious, they just act like children." (M8). 
Table 5. How they spend time with their children according to the participating fathers' viewpoints

\begin{tabular}{llll}
\hline & $f$ & & $f$ \\
\hline Playing games & 20 & Going to the cinemas & 1 \\
\hline Going on trips & 4 & Doing homework & 1 \\
\hline Chatting & 4 & Drawing & 1 \\
\hline Gardening & 3 & Going to an activity & 1 \\
\hline Watching TV & 1 & & 36 \\
\hline
\end{tabular}

The answers to the question of how the 15 fathers spend time with their children and what they do the most with the children were analyzed. In all, 20 answers included playing games, four included going on trips, four included chatting, three included gardening, one included watching TV, one included going to the cinemas, one included doing homework, one included drawing, and one included going to an activity (see Table5). Fathers' responses included "We usually play games. We'll do something in the garden. Sometimes, we draw; sometimes, we play with plasticine (play dough)" (F3) and "We play games, chat, travel. We play games like friends." (F7).

Table 6. How fathers spend time with their children according to the participating mothers' viewpoints

\begin{tabular}{llll}
\hline & $f$ & & $f$ \\
\hline Playing games & 17 & Going to the cinemas & 2 \\
\hline Watching TV & 5 & Putting the child to sleep & 2 \\
\hline Washing & 4 & Chatting & 1 \\
\hline Going to an activity & 4 & Petting the animals & 1 \\
\hline Going for a walk & 4 & Reading books & 1 \\
\hline Gardening & 3 & Getting ready for school & 1 \\
\hline Cycling & 2 & Drawing a picture & 1 \\
\hline Studying & 2 & & 50 \\
\hline
\end{tabular}

The 15 mothers responded to the question regarding how their husbands spend time with their children and what they do the most with the children. In all, 17 answers included playing games, five included watching television, four included washing, four included going to an activity, four included going for a walk, three included gardening, two included cycling, two included studying, two included going to the cinemas, two included putting the child to sleep, one included chatting, one included petting the animals, one included reading books, one included getting ready for school, and one included drawing a picture (see Table6). Some examples of the mothers' responses comprised "They always play games. Much more than I do" (M3) and "They play games the most. They play a lot of games at home and outside. They have a good time. They play more games than I do." (M7).

\section{Perception of Fatherhood}

Under this category, the present study analyzed the best and the hardest parts of fatherhood according to fathers and the best and the hardest parts of their husbands being fathers according to mothers. 
T able 7. Best part of fatherhood according to the participating fathers

\begin{tabular}{ll} 
& $f$ \\
\hline Raising a child & 7 \\
\hline Feeling the love of a child & 4 \\
\hline Becoming a role model & 3 \\
\hline Becoming a family & 2 \\
\hline Total & 15 \\
\hline
\end{tabular}

To the question "What is the best part of being a father in your opinion," seven fathers responded raising a child, four responded feeling the love of a child, three responded becoming a role model, and two responded becoming a family (see Table7). Responses such as "You're raising an individual like growing a tree. He/she is slowly growing up, and you are doing something good" (F1) and "It makes me very happy to see him/her grow up and develop. His/her development reminds me that I'm alive." (F14) are examples to the category of raising a child. Responses such as "The child hugs and kisses you and shows you love by calling you 'Father." (F6) and "The best part is your child's loving gaze, and the way they show you love." (F15) are examples of the category of feeling the love of a child. Responses such as "My eldest son's sees me as a hero. I feel proud when he pretends to be me and impersonates me. For example, I ask my wife, 'What's that outfit?,' and he asks his mother, 'What is that outfit?"' (F8) and "He tries to look like me. He tries to shave and walk like me. That is the best part of this." (F11) are examples of the category of becoming a role model. Statements such as "With him, we became a family. We were missing a piece when we did not have a child. Now, if he's not in the house, we'll get into a flap. With him/her, the missing piece of our puzzle is complete." (F2) are examples of the category of being a family.

Table 8. The hardest part of fatherhood according to the participating fathers

\begin{tabular}{ll}
\hline & $F$ \\
\hline Adapting to fatherhood & 9 \\
\hline Not having enough time for the child & 4 \\
\hline Worrying about the child's future & 4 \\
\hline Total & 17 \\
\hline
\end{tabular}

According to the responses of the participating fathers, the hardest part of fatherhood is adapting to fatherhood, not having enough time for the child, and worrying about the child's future (see Table8). In all, nine fathers responded adapting to fatherhood. Examples for this aspect consisted of the following: "For instance, it's hard to adapt to a life with children and not being able to do what you want whenever you want it. It's hard to adapt to a new life." (F9) and "For example, when he/she was sick for the first time, I didn't know what to do. It was so hard. I wanted to run away, but his father was no other than me. Getting used to being a father was really hard for me." (F12). Responses such as "I have two jobs. One shift ends, the other begins. I can only spend time with him/her on weekends. That is the hardest part for me, but everything is for him/her in the end" (F4) and "Not being able to spend time playing with him/her due to my busy and exhausting schedule is my biggest regret. I wish I could stay home longer." (F6) are examples of the category of not having enough time for the child. Answers such as "The hardest part is the concern. What happens when he/she grows up? Oh, do not let anything happen to him/her. I want him/her to be a good person. I am a little neurotic." (F13) and "Which profession will he/she 
choose? Will he/she be loved? What kind of future awaits this child? I think the hardest part is thinking about these questions. The rest is easy. The important thing is to think about his/her future." (F15) are examples of the category of worrying about the child's future.

$\mathrm{T}$ able 9. The best part of their husbands being a father according to the participating mothers

\begin{tabular}{ll} 
& $f$ \\
\hline Becoming a role model & 7 \\
\hline Feeling the love of a child & 3 \\
\hline Becoming a family & 3 \\
\hline Raising a child & 2 \\
\hline Total & 15 \\
\hline
\end{tabular}

According to the participating mothers, the best part of their husbands being a father is being a role model, feeling the love of a child, becoming a family, and raising a child (see Table9). "He sees himself in our child. He gets very happy if his son also likes what he likes. He enjoys it when his acts like him." (M11) and "I think that the children are like him. We have two sons. He says, 'I hope they look like me and act like me."' (M14) are responses to the category of being a role model. "He loves the intensity of the emotion. He likes their hugs, kisses, and them waiting for him to come home." (M3) and "He enjoys it when he/she hugs him and says I love you, being called Dad, and receiving hugs and kisses for no reason." (M7) are responses to the category of feeling the love of a child love. "I think he thinks we are a family with him/her. When we had a child, he felt he was in a family. He began staying more at home." (M2) and "The concept of family. The kid, him, and me. The presence of the children makes him happy. It was like he was the only one when the kids did not exist. When he became a father, we became a family." (M12) are responses to the category of being a family. Finally, the response "The power to guide an individual makes him happy. Teaching something new, raising him/her makes him very happy." (M1) is an example to the category of raising a child.

$\mathrm{T}$ able 10. The hardest part of their husbands being a father according to the participating mothers

\begin{tabular}{ll} 
& $f$ \\
\hline Taking responsibility & 6 \\
\hline Not having enough time for the child & 4 \\
\hline Communicating with the child & 3 \\
\hline Do not experience difficulties & 2 \\
\hline Total & 15 \\
\hline
\end{tabular}

According to the participating mothers, the hardest part of their husbands being a father can be listed as taking responsibility, not having enough time for the child, and communicating with the child. According to two participating mothers, their husbands did not experience any difficulties as a father (see Table10). "In a stressful period, meeting the needs of the child puts pressure on him; the child's desires exhaust him." (M1) and "He is fond of his own comfort. Sometimes, he complains that he couldn't rest or couldn't watch a movie; he argues that he always takes care of himself. I think the responsibility of being a father is hard on him." (M8) were statements for the category of taking responsibility. "His working hours are too long. He can't spend as much time with the child as he wants to. He sees the child for half an hour on weekdays after work or doesn't see him/her at all." (M3) and "When he leaves from work, it is the child's bedtime. Sometimes, they don't see each other at all. Sometimes I keep the kid from going to sleep, 
but then, by that time, the child gets grumpy. I mean, I think not being able to see the kid is the hardest part." (M11) were responses to the category of not having enough time for the child. Finally, "Sometimes, they get stubborn. I don't understand which one is the adult and which the child. He threatens the child by saying if you don't do that I'll do this." (M7) and "When the child is being naughty and crying, he gets angry and shouts. If he changes that side of him and talks to him instead, he will be a better father." (M12) are responses that illustrated the category of communicating with the child.

\section{Conclusion}

Being a father is a situation that develops in a different way than being a mother, and it is not as tangible of a phenomenon as the maternal relationship of "giving birth and becoming a mother." Being a father, as well as its legal and cultural aspects, is often closely related to ensuring the livelihood of the child and the mother and is perhaps the most difficult part to understand of being a man (Zeybekoglu, 2013). The fathers who participated in the study considered fatherhood as a situation that gives them happiness and responsibility and commented on the financial dimension of this obligation. Engle (1997) stated that the presence of men in the family plays a vital role in the well-being of the children and women. This support manifests itself especially in economic terms, and the lack of such support negatively affects children and women. Along with being responsible, the fathers described themselves as self-sacrificing; this perception of self-sacrifice arises with the sense of responsibility when starting a family. In addition, the fathers stated that they consider their families before themselves when making any decisions or taking steps.

The mothers who participated in the study described their spouses as involved and responsible. Fathers, who show interest toward their children, noted that within this involvement, they provided for the children's needs and took them to various activities. This involved attitude reflects the responsibilities of the fathers. According to the United Nations Convention on the Rights of the Child (2020), parents together take responsibility for the upbringing and development of the child. While this responsibility entails the high benefit of the child, it should also attribute equal roles to parents in all areas. On the contrary, the shared responsibility of the children within the family may vary depending on the mother's working situation. If the mother does not work, the responsibility for caring and education is assigned to her; if the mother is working, this responsibility is shared between the spouses (Tutkun \& Tezel Sahin, 2016). In this study, fathers consider themselves as self-sacrificing and responsible; however, the study observed that this responsibility is not reflected much in the housework. Both fathers and mothers expressed that fathers mostly play games with their children; they stated that the vast majority of the time that fathers spend with their children is for play. In addition, some fathers stated that they want to spend their game time as quality time, and in this sense, they choose to combine knowledge and skills within the game. Other studies also claim that fathers' choosing to play games as a quality time activity affects the social and emotional development of their children. However, factors such as workload and physical and mental fatigue can create obstacles while wanting to spend quality time (Turkoglu, Celikoz \& Uslu, 2013).

Another point of attention among the findings is that regarding the time fathers spent with their children, there was no mention of acts devoted to self-care of their children. Yet some mothers noted that their spouses wash and put their children to sleep. Interpretations to this aspect may be that fathers do not consider self-maintenance activities as spending quality time or that they hesitate to specify these activities. In both cases, it can be said that the participation of fathers in 
activities related to children's self-care is not very high. Previous studies focusing on the benefits of paternal involvement argued that fathers should get rid of a number of their concerns and share responsibility with the mother in the care of the child; creating common interests and strengthening communication with the child significantly affect the future years and psychosocial development of the child (Flouri, Midouhas \& Narayanan, 2016; Lamb \& Lewis, 2004; Opondo, Redshaw \& Quigley, 2017; Yavuzer, 2010). Lewis and Warren (as cited in McKeown, 2001, p. 6) stated that fathers are sensitive and responsible toward their children just like mothers, suggesting that fathers are the ones to respond to their children's basic care needs while mothers work. However, if the mother does not work, then she is the one to often shoulder this responsibility.

One of the reasons why fathers have little or no participation in meeting their children's selfcare needs may be related to the extent of paternity leave. Under maternity leave, in many countries, the period of leave granted to working mothers can be sufficient for them to recover themselves physically, spiritually, emotionally, and hormonally. The mother takes care of the baby during this time and also begins to meet the baby's basic needs. The period of legal leave granted to fathers after birth in the Turkish Republic of Northern Cyprus (TRNC) is three days (Public Officials Act, 1982). This leave grant limits the time that fathers can spend with their newborns. Although there are results that suggest longer periods of leave are associated with more frequent engagement in developmental tasks and caretaking when children are infants as well as during the first years of children's lives (Petts \& Knoester, 2018), the father, who returns to work shortly after the birth of the child, may grow distant from the aspects of care and basic needs of the child.

The study findings also allow us to assess issues related to the perception of fatherhood. The perception of fatherhood is considered an integral part of individuals' decision-making processes and the behaviors they exhibit about fatherhood. Parke (2000) underlined that the perception of fatherhood is quite effective on the behaviors of fathers. For example, if a father has a perception that feeding the child is the work of the mother, he does not exhibit any behavior to satisfy the child's need for nutrition in the process; however, he takes responsibility in this process if he has a perception that he is also responsible for the child's nutrition. When the responses of fathers who participated in the study were evaluated for the perception of fatherhood for the question "What is the best part of fatherhood?" seven fathers answered raising a child, four answered feeling the love of children, three fathers answered becoming role models, and two fathers answered becoming a family. When evaluating the responses of mothers, it was determined that they ranked their husbands' best part of fatherhood in the form of becoming a role model, feeling the love of a child, becoming a family, and raising a child.

Given the responses of fathers, it is believed that fathers have a positive perception of taking care of and supporting the children, i.e., undertaking new responsibilities related to the child. This aspect suggests that fathers have a positive perception of the issues of meeting the needs of their children in the process of raising them and taking care of them. In addition to this, phrases such as being role models and being together are considered to be an indication that they have the sense of safeguarding their children (Tol \& Taskan, 2018). These responses reveal that fathers are happy to actively participate in their children's lives and contribute to their upbringing. As a result of the research conducted by Gul (2019), fathers who participated in the study expressed that the positive facets of paternal roles were to fulfill their responsibilities related to their children and spend time with their children. When the responses of mothers were evaluated, they also gave similar responses to the fathers. In general, the responses of both parents concluded that fathers are pleased to be role models for their children and to have a family completed with the children. The presence of a father figure, eager to become a role model in the children's lives, positively 
contributes to the development of the children. This factor suggests that fathers hold a vital role in the life of the child (Lewis \& Lamb, 2003; Coral \& Sahin, 2017; Honor, 2012).

Most of the fathers involved in the study expressed that the hardest part of fatherhood was adapting to fatherhood followed by not being able to spend time with the child and worrying about the child's future. Most of the mothers stated that the hardest part for their spouses was to take responsibility for their children. This response was followed by not being able to spend time with the child and the inability to communicate with them. According to the responses of the mothers, only two fathers did not experience any difficulties with fatherhood. When the responses of fathers and mothers were evaluated, it is believed that fathers have a traditional perception of fatherhood, both according to their own responses and the responses of their wives. The traditional father is usually portrayed as a person who does not take responsibility for the self-care of the child, who economically provides for the livelihood of the house, and is perceived as a source of authority in the family. These fathers are usually individuals who do not take part in matters related to childcare and have a bias against gender roles. In addition, traditional fathers perceive themselves as the breadwinner of the family and consider that they fulfill their responsibilities through economic contribution. The "Masculinity and Fatherhood" report published by ACEV (Tol \& Taskan 2018) found that more than a third of the fathers involved in the study exhibited "traditional father" characteristics. Dagseven (2020) found a similar finding to this research in the results of a maternity report in Cyprus. Most of the mothers who participated in the study stated that they turned to their own families for support and responsibility in childcare and that their husbands did not share the parental role with them equally. Contrary to the belief, motherhood and fatherhood are not inherent characteristics of individuals. Motherhood and fatherhood are defined as attitudes and behaviors that are learned, exhibited, and evaluated (Baydar, Akcinar \& Imer, 2012; Zeybekoglu, 2013). The concept of fatherhood is used to describe more behavioral aspect such as dealing with the care and needs of the child and taking responsibility. The fact that in general the mother is perceived as the primary caretaker in the society and that this role is attached to the mother as a gender role causes an obstacle in the process of fathers' perception of their responsibilities. The roles that society imposes on fatherhood not only affect how fathers perceive fatherhood but also have a complicating or facilitating effect on this development. A traditional viewpoint toward fatherhood depicts the father as the head of the house, the provider, and an authoritative person and restricts the father's participation in taking responsibility in childcare (Eggebeen \& Knoester, 2001; Lewis \& Lamb, 2003; Coral \& Hawk, 2017). The research report "Fatherhood among Parenting, Masculinity, and Work-Life in Turkey" (Bozok, 2018) claimed that most of the fathers involved in the research show a sexist attitude toward domestic roles and noted that opposed to the idea of both themselves and their children taking responsibility for household chores. Along with the society, mothers and fathers have been modernizing gender roles; fathers' perspective on the childcare responsibility is observed to be changing, and the participation of fathers in the process of taking accountability for the child is increasing (Cabrera et al., 2000; Williams, 2008). Although some research studies (Kagitçıbaşı, 2014; Onur, 2012) revealed that today there is a transition from traditional to new fatherhood, this study found that fathers perception of fatherhood still reflects a more traditional perception.

\section{Suggestions}

Paternal involvement represents the moderate and close relationship established between the father and the child. Babies attach to their fathers at the end of the first year of their lives, even if their fathers spend very little time with them (Cox, Owen \& Henderson, 1992). At this point, the 
quality of the time spent between the father and the child gains importance. Studies conducted in America and Europe show that paternal involvement is a major contributor to children's intellectual, social, and emotional development. According to Cano, Perales \& Baxter (2019), the quality of the relationship between the father and the child and the father's response to the child's needs are the determinants of the cognitive performance of the child. Positive paternal involvement beneficially affects the social, behavioral, cognitive, and psychological development of the child (Aydogmus, 2018; Sarkadi et al., 2007) and contributes to the development of the child's language (Cabrera, Shann \& Tamis Le Monda, 2007). In the light of this information, generating awareness in the society about the importance of paternal involvement and the effect of fathers spending quality time with their children is vital; thus, formulating and implementing father support programs is advised.

Paternal involvement can be effective in forming gender roles and stereotypes, especially in preschool children. Dick (2011) stated that fatherhood is also largely influenced by the man's relationship with his own father. The quality of this relationship, the emotional support of the father, and his being there also affected the child. Therefore, for future fathers to interact more with their own children, today's fathers must become more participatory. Therefore, activities related to parenthood can be included in higher education programs and public education studies. Short-term training can be organized wherein pregnant women and their spouses in particular are given the knowledge and skills in preparing to become parents. At this point, a review of programs, textbooks, and activities at various school levels starting from the preschool period to break down the stereotypes related to paternal roles is recommended.

A better understanding of the roles and participation of fathers in the family will also contribute to the future development of the country's programs and policies for family members and family relationships (Carrillo et al., 2016). In this context, considering the study findings, reviewing the length of paternity leave in the TRNC, updating the curriculum at schools with this aim, training the teachers who are going to be teaching this curriculum, weighing more toward mother and father trainings in adult education, and developing many such programs and policies in various areas, thereby remedying the deficiency in the country, are advised. Moreover, other research on fatherhood should be conducted because the findings of new research studies will enrich this study's results, thereby increasing the contribution to literature. 


\section{References:}

Aksoy, A. B., \& Tatlı, S. (2019). The investigation of relationship between of fathers perception of fatherhood role and relationship of fathers with their pre-school children. Journal of Institute of Social Sciences, 10(1), 1-22.

Alicik, H. (1997). Kıbrıs Türk aile yapısı. Ișık Kitabevi.

Atmaca Koçak, A. (2004). Evaluation report of the father support program. Anne Çocuk Eğitim

Vakfı. https://www.acev.org/en/directory/evaluation-report-of-the-father-support-program/

Aydoğmuș, S. (2018). Relationship between cognitive style of 48-72 months old children and father involvement. [Unpublished master's thesis]. Maltepe University.

Baydar, N., Akçınar, B., \& İmer, N. (2012). Çevre, sosyoekonomik bağlam ve ana babalık. In M. Sayıl \& B. Yağmurlu (Eds.), Ana babalık: Kuram ve araştırma (pp. 81-127). Koç Üniversitesi Yayınları.

Bayer, A. (2013). Family in changing structure. Şırnak University Journal of Divinity Faculty, 4(8), 101-129.

Bayer, A. (2020). Family in modernization: Motherhood and fatherhood. Tevilat, 1(1), 35-60. https://doi.org/10.5281/zenodo.4414805

Beyazıt, U., \& Mağden, D. (2015). The examination between hypergender ideology and perception of fatherhood role among male students attending to university. Journal of Social Sciences, 7(3), 207-225.

Bozok, M. (2018). Ebeveynlik, erkeklik ve çalışma hayatı arasında Türkiye'de babalık.

Anne Çocuk Eğitim Vakfı. https://www.acev.org/wp-

content/uploads/2018/05/EbeveynlikErkeklikCalismaHayati.pdf

Bronte-Tinkew, J., Carrano, J., \& Guzman, L. (2006). Resident fathers' perceptions of their roles and links to involvement with infants. Fathering: A Journal of Theory, Research \& Practice About Men as Fathers, 4(3), 254-285. https://doi.org/10.3149/fth.0403.254

Cabrera, N. J., Shannon, J. D., \& Tamis-LeMonda, C. S. (2007). Fathers' influence on their children's cognitive and emotional development: From toddlers to pre-k. Development Science, 11(4), 208-213.

Cabrera, N. J., Tamis-LeMonda, C. S., Bradley, R. H., Hofferth, S., \& Lamb, M. E. (2000).

Fatherhood in the twenty-first century. Child Development, 71(1), 127-136.

Cano, T., Perales, F., \& Baxter, J. (2019). A matter of time: Father involvement and child cognitive outcomes. Journal of Marriage and Family, 81(1), 164-184.

https://doi.org/10.1111/jomf.12532 Carrillo, S., Bermudez, M., Suarez, L., Gutierrez, M. C., \&

Delgado, X. (2016). Father's perceptions of their role and involvement in the family: A qualitative study in a Colombian sample. Revista Costarricense de Psicologia, 35(2), 101-118.

Coltrane, S. (1995). The future of fatherhood: Social, demographic and economic influence on men's family involvement. In W. Marsiglio (Ed.), Fatherhood contemporary theory, research and social policy (pp 255-274). Sage Publications.

Cox, M. J., Owen, M. T., \& Henderson, V. K. (1992). Prediction of infant-father and infantmother attachment. Developmental Psychology, 28(3), 474-483. https://doi.org/10.1037/00121649.28.3.474

Creswell, J. W. (2013). Nitel araștirma yöntemleri (M. Bütün \& S. B. Demir, Trans.). Siyasal Kitapevi.

Cullen, L. T., \& Grossman, L. (2007). Fatherhood 2.0. Time, 170(16), 63-66. 
Dağseven, J. Ş. (2020). Motherhood in Cyprus. Findings and recommendations on the needs of mothers in Cyprus. Motherhood Truths. http://motherhoodtruths.com/wpcontent/uploads/2020/09/Motherhood-in-Cyprus-Report-ENG.pdf

Dick, G. L. (2011). The changing role of fatherhood: The father as a provider of self object

functions. Psychoanalytic Social $\quad$ Work, $18, \quad 125$. https://doi.org/10.1080/15228878.2011.611786

Eerola, P. (2015). Responsible fatherhood: A narrative approach [Unpublished doctoral dissertation]. University of Jyväskylä.

Eggebeen, D. J., \& Knoester, C. (2001). Does fatherhood matter for men? Journal of Marriage and Family, 63(2), 381-393.

Ekici, F. Y. (2014). Change and transformation of Turkish family structure and evaluation of the elements that affecting this change and transformation. The Journal of Academic Social Science Studies (JASSS), 30, 209-224.

Engle, P. L. (1997). The role of men in families: Achieving gender equity and supporting children.

Gender and Development, 5(2), 31-40.

Evans, C. (1997). Turkish fathers' attitudes to and involvement in their fathering role: A low socio-economic sample [Unpublished master's thesis]. Boğaziçi University.

Flouri, E., Midouhas, E., \& Narayanan, M. K. (2016). The relationship between father involvement and child problem behaviour in intact families: A 7 year cross lagged study. Journal of Abnormal Child Psychology, 44, 1011-1021. https://doi.org/10.1007/s10802-015-0077-9

Garfield, C. F., \& Chung, P. J. (2006). A qualitative study of early differences in fathers' expectations of their child care responsibilities. Ambulatory Pediatrics, 6(4), 215-220. https://doi.org/10.1016/j.ambp.2006.04.001

Gül, Ş. (2019). Examination over the perceptions of parents who have children between the ages 3 and 6 towards paternity role and view of the adequacy of paternity role [Unpublished master's thesis]. Hacettepe University.

Gültekin Akduman, G., \& Türkoğlu, D. (2013). Okul öncesi dönem çocuğu olan babaların babalık rollerini algılamaları ile çocuklarının davranış problemleri arasındaki ilişkinin incelenmesi. Uluslararası Hakemli Aile Çocuk ve Eğitim Dergisi, 1 (1), 1-17.

Güngörmüş, O. (2010). Baba-çocuk ilişkisi, ana-baba okulu. Remzi Kitabevi.

Gürşimşek, I., Kefi, S., \& Girgın, G. (2007). Investigation of variables related with father involvement in early childhood education. H. U. Journal of Education, 33, 181-191.

Güzel, H., \& Tüfekçi, A. (2021). Examination of the relationship between fathers' relationships with their children and their fatherhood role perception: The case of Gaziantep. Kalem Eğitim ve İnsan Bilimleri Dergisi, 11(2), 439-465. http://doi.org/10.23863/kalem.2021.182

Kağıtçıbaşı, Ç. (2014). Family and human development across cultures: A view from the other side. Psychology Press.

Public Officials Act (1982). Çalışma saatleri, ek çalışma ve izinler. http://www.mevzuat.kamunet.net/mmd/yasalar/Kamu_Gorevlileri_Yasasi.pdf

Kutz, M. I. (1994). Parental involvement and perception toward fathers' roles: A comparison between Japan and the United States. Journal of Family Issues, 15(1), 30-48.

Kuzgun, Y., \& Sevim, S. A. (2004). The relationship between attitudes towards women's work roles and religious tendency. Ankara University Journal of Faculty of Educational Sciences, 37(1), 14-27. 
Lamb, M. E., \& Lewis, C. (2004). The development and significance of father-child relationships in two-parent families. In M. E. Lamb (Ed.), The role of the father in child development (pp. 272-306). Wiley.

Lewis, C., \& Lamb, M. E. (2003). Fathers' influences on children's development: The evidence from two parent families. European Journal of Psychology of Education, 18(2), 211228. Maxwell, J. A. (2008). Designing a qualitative study. In L. Bickman \& D. J. Rog (Eds.), The SAGE handbook of applied social research methods (pp.214-253). Sage Publications. McKeown, K. (2001). Fathers and families: Research and reflection on key questions. Lenus, The Irish Health Repository. https://www.lenus.ie/handle/10147/285260

Mercan, Z., \& Șahin, F. T. (2017). The father's role and the fathers role perception in different cultures. International Journal of Early Childhood Education Studies, 2(2), 1-10. Merriam, S. B., \& Grenier, R. S. (2019). Qualitative research in practice: Examples for discussion and analysis. Jossey-Bass Publishers

Miles, M, B., \& Huberman, A. M. (1994). Qualitative data analysis: An expanded sourcebook. Sage Publications.

Model, S. (1981). Housework by husbands determinants and implications. Journal of Family Issues, 2(2), 225-237. https://doi.org/10.1177/0192513X8100200207

Neuman, W. L. (2008). Toplumsal araştırma yöntemleri: Nitel ve nicel yaklaşımlar (Ö. Sedef, Trans.) Yayınodası.

NICHD Early Child Care Research Network (2000). Factors associated with fathers' caregiving activities and sensitivity with young children. Journal of Family Psychology, 14, 200-219.

Onur, B. (2012). Çocukluğun ve çocuk yetiștirmenin tarihi. In M. Sayıl, \& B. Yağmurlu (Eds.), Ana babalık: Kuram ve araştırma (pp. 19-59). Koç Üniversitesi Yayınları.

Opondo, C., Redshaw, M., \& Quigley, M. A. (2017). Association between father involvement attitudes in early child-rearing and depressive symptoms in the pre-adolescent period in a UK birth cohort. Journal of Affective Disorders, 221, 115-122. https://doi.org/10.1016/j.jad.2017.06.010 Ögüt, Ü. (1998). Father involvement with respect to the age and gender of preschool children and the employment status of the mother in a sample of upper and middle socio-economic status Turkish father [Unpublished master's thesis]. Boğaziçi University.

Parke, R. D. (2000). Father involvement: A developmental psychological perspective. Marriage \& Family Review, 29(2-3), 43-58. https://doi.org/10.1300/J002v29n02_04

Parke, R. D. (2002). Foreword. In S. M. Hanson, \& F. W. Bozett (Eds.), Dimensions of fatherhood (pp. 9-12). Sage Publications.

Parke, R. D. (2004). Fathers, families, and the future: A plethora of plausible predictions. Merrill-Palmer Quarterly, 50(4), 456-470. https://doi.org/10.1353/mpq.2004.0033

Petts, R. J., \& Knoester, C. (2018). Paternity leave-taking and father engagement. Journal of Marriage and Family, 80(5), 1144-1162. https://doi.org/10.1111/jomf.12494

Pontes C. M, Osorio M. M., \& Alexandrino, A. C. (2009). Building a place for the father as an ally for breast feeding. Midwifery 25(2), 195-202. http://dx.doi.org/10.1016/j.midw.2006.09.004 Richardson, J. (1995). Achieving gender equality in families: The role of males. UNICEF Office of Research-Innocenti. https://www.unicef-irc.org/publications/pdf/igs_gender.pdf

Rohner, R. P., \& Veneziano, R. A. (2001). The importance of father love: History and contemporary evidence. Review of General Psychology, 5(4), 382-405. https://doi.org/ 10.1037/1089-2680.5.4.382

Russell, G. (1982). Shared care giving families: An Australian study. In M. E. Lamb (Ed.), Nontraditional families parenting and child development (pp. 139-171). Erlbaum. 
Sarkadi, A., Kristiansson, R., Oberklaid, F., \& Bremberg, S. (2007). Fathers' involvement and children's developmental outcomes: A systematic review of longitudinal studies. Acta Pediatrica, 97(2), 153-158. https://doi.org/10.1111/j.1651-2227.2007.00572.x

Saygılı, S. (2008). Ruhen ve bedenen sağlıklı çocuk yetiştirmek. Hayat Yayıcılı.

Scarzello, D., Arace, A., \& Prino, L. E. (2016). Parental practices of Italian mothers and fathers during early infancy: The role of knowledge about parenting and child development. Infant Behavior and Development, 44, 133-143. https://doi.org/10.1016/j.infbeh.2016.06.006

Shafaie, S., Mayers, G., Al-Maadadi, F. Y., Coughlin, C., \& Wooldridge, D. G. (2014). Females' perception of the role of fathers in caring for children. International Journal of Education and Social Sciences, 1(3), 20-31.

Stubley, T. L., Rojas, M., \& McCroy, C. (2015). Father's perceptions about their fathering role. Journal of Arts and Humanities, 4(4), 33-39.

Summers, J. A., Raikes, H., Butler, J., Spicer, P., Pan, B., Shaw, S., Langager, M., McAllister, C., \& Johnson, M. K. (1999). Low-income fathers' and mothers' perceptions of the father role: A qualitative study in four early head start communities. Infant Mental Health Journal, 20(3), 291304.

Telli, A. A., \& Özhan, H. (2016). Determination of fatherhood role perception of fathers with children aged 3-6 years and the affecting factors. İmir Dr. Behçet Uz Çocuk Hast. Dergisi, 6(2), 127-134. https://dx.doi.org/10.5222/buchd.2016.127

Tol, U. U., \& Taşkan, D. (2018). Erkeklik ve babalık halleri. Anne Çocuk Eğitim Vakfı. https://www.acev.org/wp-content/uploads/2018/05/ErkeklikVeBabalikHalleri.pdf

Tutkun, C., \& Tezel Şahin, F. (2016). Naturalistic observations of mother, father and children: Is it mother and child in a bookstore environment? Or father and child? Kastamonu Education Journal, 24(5), 2293-2308.

Türkoğlu, B., Çeliköz, N., \& Uslu, M. (2013). Fathers' views about perceptions of quality time with their children between the ages of 3-6. Journal of Research in Education and Teaching, 2(2), 54-71.

Uluş, Y. (2015). Evaluation of the family understanding and Turkish family in terms of our cultural and social reality. PESA International Journal of Social Studies, 1(1), 15-24.

United Nations Convention on the Rights of the Child. (2020). Convention on the rights of the child. https://www.ohchr.org/Documents/ProfessionalInterest/crc.pdf

US Census Bureau. (2013). Facts for features: Father's Day, June 16, 2013. https://www.census.gov/content/dam/Census/newsroom/facts-for-features/2013/cb13ff13_fathersday.pdf

Williams, S. (2008). What is fatherhood? Searching for the reflexive father. Sociology, 42(3), 487-502.

Yavuzer, H. (2010). Anne olmak. Remzi Kitabevi.

Yıldırım, A., \& Şimşek, H. (2016). Sosyal bilimlerde nitel araştırma yöntemleri. Seçkin

Yayınc1lik.

Yllmazçetin, C. (2003) The relation between father involvement and behavioral problems of pre adolescents [Unpublished master's thesis]. Boğaziçi University.

Yogman, M., \& Garfield, C. F., \& Committee on Psychosocial Aspects of Child and Family Health (2016). Fathers' roles in the care and development of their children: The role of pediatricians.

Pediatrics, 138(1), 1-15. https://doi.org/10.1542/peds.2016-1128

Zeybekoğlu, Ö. (2013). Contemporary fatherhood and the family from the male perspectives. Mediterranean Journal of Humanities, 3(2), 297-328. 